\title{
Overview of Usual Food Leftovers in Inpatients at the Jailolo Regional General Hospital, West Halmahera Regency
}

\author{
Anita Wati T. K. Hi. Mustafa ${ }^{1}$, Nizmawaty Amra ${ }^{2}$ \\ ${ }^{12}$ Jurusan Gizi, Poltekkes Kemenkes Ternate, Indonesia
}

\begin{abstract}
Hospital nutrition services are part of a complete health service. Each hospital provides nutritional services, not only providing food for patients and staff, but the most important thing is the provision of food that meets the needs of human metabolism for recovery during treatment. Food waste is the amount of food that is not eaten or not consumed by the patient. The purpose of this study was to determine the type of food and the amount of leftover food that was not consumed by patients who received regular food at the Jailolo Hospital. The type of research used is descriptive with sampling using purposive sampling as many as 20 respondents. The results showed that of the 20 respondents using the Comstock method, the average patient leftover food left a lot $(>20 \%)$ in the staple food type $40 \%$, animal side dishes $35 \%$, vegetable side dishes $30 \%$, vegetables $30 \%$ and fruit $40 \%$. Based on the results of the study, it can be concluded that most of the respondents still left a lot of food and it is recommended for nutrition installations to improve the quality and taste of the food served so that there is no more food left.
\end{abstract}

\section{Introduction}

Nutrition services in hospitals (PGRS) are an integral part of plenary health services in hospitals with several activities, including inpatient nutrition services which are a series of activities to meet the nutritional needs of patients through food according to the disease they are suffering from. The implementation of nutrition services in hospitals is adjusted to the guidelines for hospital nutrition services (PGRS) in 2013(Kementerian Kesehatan RI, 2013). Hospital food delivery is a series of activities starting from menu planning to distributing food to patients. Food service activities are part of the hospital's nutrition installation activities to meet the nutritional intake of patients(Nareswara, 2017; Paruntu, 2013).

The success of a nutrition service is related to, among other things, the patient's acceptance of the food served, so that it is one way of determining a simple evaluation and can be used as an indicator of the success of nutritional services (Uyami, Hendriyani, \& Wijaningsih, 2014). One of the factors that determine the patient's food waste is the variety of menus provided by the hospital, variations in the menu of staple foods, animal, vegetable, vegetable and fruit side dishes can increase the patient's desire to eat and can trigger food acceptance so that patients do not consume additional food outside the home sick. Several factors that affect the patient's food acceptance are the taste of the food that is not good, the level of adaptation to the hospital environment which is different from the home environment so that it affects the motivation for food(Uyami et al., 2014). Hospital accreditation standards state that nutritional services are not only providing food for patients and staff, but the most important thing is the provision of food that meets human metabolic needs for recovery and correcting metabolic disorders(Kementerian Kesehatan RI, 2013)

The problem with nutrition services in hospitals that often occurs is the amount of leftover food from inpatients, which means that the purpose of nutrition services is not quite right. Therefore, it is necessary to measure the leftovers served. Measuring leftovers serves to determine the patient's acceptance of the food served(Paruntu, 2013). This means that the analysis of food waste is a way to evaluate the nutritional services that have been provided, especially food services(Kementerian Kesehatan RI, 2013). 
Food waste (plate waste), in this case is the weight of food on the plate or plate that is not spent or thrown away by the patient which is served as a percentage(Williams \& Walton, 2011). Leftover food is an indicator of the success of nutrition services in hospitals that are adjusted to the patient's condition and based on clinical conditions, nutritional status and body metabolic status. The state of nutrition is very influential on the healing process of the disease, otherwise the course of the disease can affect the nutritional state of the patient. It often happens that the patient's condition gets worse because his nutritional state is not considered. This is caused by not meeting the body's nutritional needs for the improvement of body organs(Kementerian Kesehatan RI, 2013).

In Indonesia, there have been many studies on food waste, such as Nida (2011) at the Mental Hospital of Sambang Lihum Banjarmasin, the average patient leftover food left a lot, which is $>50 \%$ with details on the type of vegetable food of $67.8 \%$ animal side dishes remaining 52, $2 \%$ and the remaining $50.8 \%$ vegetable side dishes. Likewise with Munawar's research (2011) at Hasan Sadikin Hospital in Bandung, the remaining soft food of class 3 patients in a day is 31.20\%(Tanuwijaya, Sembiring, Dini, Arfiani, \& Wani, 2018).

According to Kepmenkes No.129/Menkes/SK/II/2008 concerning minimum hospital service standards (SPM), the remaining food that is not eaten by patients is as much as $20 \%$. The fulfillment of these requirements is an indicator of the success of nutrition services in every hospital in Indonesia.

Based on data from the nutrition installation at the Jailolo Hospital in February 2020, 160 patients received regular/soft food and there were leftovers from ordinary food found on the patient's food plate.

\section{Method}

The method used to determine food waste can be done in two ways, namely:

a. Food weighing (weight method/weight plate waste)

The food weighing method is one of the quantitative consumption survey methods. This is used with the aim of knowing accurately how a person's nutrient intake is. In a special place, such as in an institution where someone lives together, this method is very helpful in determining food consumption correctly and appropriately(Hardinsyah \& Supariasa, 2016).

This is because the food they eat already knows the type, portion, size, and brand, composition, all of which can be recorded and weighed by the officer. This is showing the actual intake (Actual intake). This method has the disadvantage that it requires a lot of time, special equipment, good cooperation with respondents, and trained officers(Nuryati, 2008).

The percentage of leftovers is calculated by comparing leftovers with standard hospital food portions times $100 \%$ or by the formula: Food Leftovers $(\%)$

$$
=\frac{\sum \text { Makanan yang tersisa }(\mathrm{gr})}{\text { Standar porsi makanan rumah sakit }(\mathrm{gr})} \times 100
$$

Sumber: (Kemenkes RI nomor 129, 2008) tentang Standar Pelayanan Minimal Rumah Sakit.

\section{b. Visual Appraisal Method Comstock (Visual Method)}

Visual estimation method is a method of measuring or estimating by observing/visualizing the amount of leftover food on the plate after the respondent finishes eating. An assessment is made for each type of dish so that it can be seen which dishes are not consumed(Wayansari, Anwar, \& Amri, 2018). In this method, leftovers are measured by visually estimating the amount of leftovers for each type of dish. The results of this estimate can be expressed in grams or in the form of a score when using a measurement scale(Nuryati, 2008). The visual comstock method is expressed in terms of 6 points and estimated in terms of $(\%)$ leftovers, as follows:

Table 1. The measurement scale for evaluating food waste uses a 6-point scale 


\begin{tabular}{|l|l|l|l|}
\hline Score image & Leftovers score & Food score criteria & Scale \\
\hline & $0 \%$ & Food out & 0 \\
\hline & $25 \%$ & Leftovers $1 / 4$ porsi & 1 \\
\hline & $50 \%$ & Leftovers $1 / 2$ porsi & 2 \\
\hline & $75 \%$ & Leftovers 3/4 porsi & 3 \\
\hline & $95 \%$ & $\begin{array}{l}\text { Leftovers are almost } \\
\text { whole }\end{array}$ & 4 \\
\hline & $100 \%$ & Makanan utuh & 5 \\
\hline
\end{tabular}

Sumber: (Metode taksiran visual Comstock, Pierre dan Mackierman 1981)

\section{Result and Discussion}

a. Tuna Fish Stick Product Overview

Fish sticks are a type of snack product made from flour and substituted for tuna meat with a composition of $300 \mathrm{~g}$ of tuna meat, $500 \mathrm{~g}$ of wheat flour, $2500 \mathrm{~g}$ of tapioca flour, $175 \mathrm{ml}$ of liquid coconut milk, $125 \mathrm{~g}$ of butter, 1 chicken egg, $20 \mathrm{~g}$ salt, $100 \mathrm{~g}$ scallion, and $50 \mathrm{~g}$ garlic.

1. Organoleptic Test

a) Color

The results of the level of organoleptic quality testing, especially on the color of tuna fish sticks, are in table 2 below:

Table 2. Organoleptic Quality on Color of Tuna Fish Sticks on Untrained Panelists

\begin{tabular}{|l|l|l|}
\hline Rasa & $\mathrm{n}$ & $\%$ \\
\hline Very much like & 8 & 26,7 \\
\hline Really like & 5 & 16,7 \\
\hline Like & 12 & 40 \\
\hline Slightly like & 4 & 13,3 \\
\hline Slightly dislike & 1 & 3,3 \\
\hline Total & 30 & 100 \\
\hline
\end{tabular}

Source: Primary Data, 2020

Based on the results of the organoleptic quality test in table 2, it shows that the panelists who stated that they liked the color of the tuna sticks were 12 people (40\%), very much liked the color of the tuna sticks as many as 8 people (26.7\%), really liked the color of the sticks. tuna fish as many as 5 people $(16.7 \%)$, slightly like the color of tuna fish sticks as many as 4 people (13.3\%), and slightly dislike the color of tuna fish sticks as much as 1 person $(3.3 \%)$.

2. Aroma

The level of research results on organoleptic quality testing, especially on the aroma of tuna fish sticks in table 3 below:

Table 3. Organoleptic Quality of the Aroma of Tuna Fish Sticks on Untrained Panelists

\begin{tabular}{|l|l|l|}
\hline Rasa & $\mathrm{n}$ & $\%$ \\
\hline Very much like & 6 & 20 \\
\hline
\end{tabular}


Source: Primary Data, 2020

\begin{tabular}{|l|l|l|}
\hline Really like & 10 & 33,3 \\
\hline Like & 11 & 36,7 \\
\hline Slightly like & 2 & 6,7 \\
\hline Not Like & 1 & 3,3 \\
\hline Total & 30 & 100 \\
\hline
\end{tabular}

Based on the results of the organoleptic quality test in table 3, it shows that the panelists who stated that they liked the smell of tuna fish sticks were 11 people (36.7\%), really liked the smell of tuna fish sticks as many as 10 people $(33.3 \%)$, really liked the smell of tuna fish sticks. 6 people $(20 \%)$, did not like the smell of tuna fish sticks as much as 2 people $(6.7 \%)$, and did not like the smell of tuna fish sticks as much as 1 person $(3.3 \%)$.

\section{Taste}

The panelists' level of preference on organoleptic quality testing, especially on the taste of tuna fish sticks, is shown in table 4 below:

Table 4. Organoleptic Quality on the Taste of Tuna Fish Sticks in Untrained Panelists

\begin{tabular}{|l|l|l|}
\hline Rasa & $\mathrm{n}$ & $\%$ \\
\hline Very much like & 8 & 26,7 \\
\hline Really like & 7 & 23,3 \\
\hline Like & 11 & 36,7 \\
\hline Slightly like & 3 & 10 \\
\hline Netral & 1 & 3,3 \\
\hline Total & 30 & 100 \\
\hline
\end{tabular}

Source: Primary Data, 2020

Based on the results of organoleptic quality testing in Table 9 shows that the panelists who like the taste of tuna fish sticks are 11 people (36.7\%), very much like the taste of tuna fish sticks as many as 8 people (26.7\%), really like the taste tuna fish sticks as many as 7 people $(23.3 \%)$, slightly like the taste of tuna fish sticks as many as 3 people (10\%), and neutral on tuna fish sticks as much as 1 person.

4. Texture

The results of organoleptic quality testing, especially on tuna fish sticks, are shown in Table 5 below:

Table 5. Organoleptic Quality on Texture Analysis of Tuna Fish Sticks on Untrained Panelists

\begin{tabular}{|l|l|l|}
\hline Rasa & $\mathrm{n}$ & $\%$ \\
\hline Very much like & 9 & 30 \\
\hline Really like & 10 & 33,3 \\
\hline Like & 8 & 26,7 \\
\hline Slightly like & 2 & 6,7 \\
\hline Not Like & 1 & 3,3 \\
\hline Total & 30 & 100 \\
\hline
\end{tabular}

Source: Primary Data, 2020

Based on the results of the organoleptic quality test in table 5, it shows that the panelists who stated that they really liked the texture of tuna fish sticks were 10 people $(33.3 \%)$, really liked the texture of tuna sticks as many as 9 people (30\%), liked the texture of the sticks. tuna fish as many as 8 people $(26,7 \%)$, slightly dislike the texture of tuna fish sticks 2 people $(6,7 \%)$, and do not like the texture of tuna fish sticks as much 
as 1 person $(3.3 \%)$.

\section{Protein Test}

Table 6. Protein Test on Tuna Fish Sticks

\begin{tabular}{|l|l|l|}
\hline Sample & \multicolumn{2}{|l|}{ Protein } \\
\cline { 2 - 3 } & $\begin{array}{l}\text { Test } \\
\text { result }\end{array}$ & Unit \\
\hline $\begin{array}{l}\text { Tuna fish stick } \\
\text { product } 100 \mathrm{~g}\end{array}$ & 11,12 & $\%$ \\
\hline
\end{tabular}

Source: Primary Data, 2020

Based on the results of protein testing using the Kjeldhal method carried out at UPT. The Basic and Integrated Laboratory of the University of Khairun Ternate obtained a total protein yield of $11.12 \%$ per 100 $\mathrm{g}$ of tuna fish sticks.

\section{Conclusion}

1. Most of the untrained panelists liked the color of the tuna fish sticks.

2. Most of the untrained panelists liked the smell of tuna fish sticks.

3. Most of the untrained panelists liked the taste of tuna fish sticks.

4. Most of the untrained panelists liked the texture of tuna fish sticks.

5. Protein content in tuna fish sticks at UPT. The Basic and Integrated Laboratory of the University of Khairun Ternate obtained a total protein yield of $11.12 \%$ per $100 \mathrm{~g}$.

\section{References}

1. Hardinsyah, \& Supariasa. (2016). Ilmu Gizi Teori dan Aplikasi. Jakarta: Buku Kedokteran EGC.

2. Kementerian Kesehatan RI. (2013). Pedoman Pelayanan Gizi Rumah Sakit Jakarta: Kementerian Kesehatan RI.

3. Nareswara, A. S. (2017). Hubungan Kepuasan Pasien dari Kualitas Makanan Rumah Sakit dengan Sisa Makanan di RSUD Kota Semarang. Ilmu Gizi Indonesia, 1(1), 34-39.

4. Nida, K. (2011). Faktor-Faktor yang Berhubungan dengan Sisa Makanan Pasien Rawat Inap di Rumah Sakit Jiwa Sambang Lihum. Skripsi. Kalimantan Selatan: Sekolah Tinggi Ilmu Kesehatan Husada Borneo Banjarbaru.

5. Nuryati, P. (2008). Hubungan antara Waktu Penyajian, Penampilan dan Rasa Makan dengan Sisa Makanan Pada Pasien Rawat Inap Dewasa di RS Bakti Wira Tamtama Semarang. Universitas Muhammadiyah Semarang, Semarang.

6. Paruntu, O. L. (2013). Status Gizi dan Penyelenggaraan Makanan Diet Pasien Rawat Inap di Blu Prof. Dr. RD Kandou Manado. Jurnal GIZIDO, 5(2), 117-126.

7. Tanuwijaya, L. K., Sembiring, L. G., Dini, C. Y., Arfiani, E. P., \& Wani, Y. A. (2018). Sisa Makanan Pasien Rawat Inap: Analisis Kualitatif. Indonesian Journal of Human Nutrition, 5(1), 5161.

8. Uyami, U., Hendriyani, H., \& Wijaningsih, W. (2014). Perbedaan Daya Terima, Sisa dan Asupan Makanan Pada Pasien Dengan Menu Pilihan dan Menu Standar di RSUD Sunan Kalijaga Demak. Jurnal Riset Gizi, 2(1), 1-6.

9. Wayansari, L., Anwar, I. Z., \& Amri, Z. (2018). Manajemen Sistem Penyelenggaraan Makanan Institusi. Kementrian Kesehatan Republik Indonesia.

10. Williams, P., \& Walton, K. (2011). Plate Waste in Hospitals and Strategies for Change. e-SPEN, the European e-Journal of Clinical Nutrition and Metabolism, 6(6), e235-e241. 